ника образовался нарывъ съ свищевымъ отверстіемъ, а за. тьмы развился sepsis, оть чего больной умерт. При вскрытіп обваружено: поверхностный саries позвонвовъ отъ 10-го грудного до 2-го поясничнаго, абсцессь въ толщ' m. psoatis, свищевое отверстіе въ области бедра, phlebitis v. femoralis; омьлотворенный туберкуль въ печени; туберкулезный нефрать. Саинной мозгъ, мозговыя оболочпи и нервы не представляли измыненій. (Дандыя мивроскопическаго изсльдованія нервноё спстемы не приводятся. По мнбнію автора туберкулезъ позвоночника не им'иль никакого отношенія къ бывшему въ 1905 г. спмдтомокомплексу. Тогда больной представляль только полиневритическія разстройства, прдчемь повышеніе рефлексовъ обусловливалось двойнымъ механизмомь: 1) Пониженіемь тонуса сгибателей бедра и 2) ивдивидуальною болье сильною возбудительностью даннаго рефлекса.

\title{
Н. Осокинь.
}

G. Roussy. Два случая пораженія зрптельнаго бугра. Deux nouveaux cos de lésions de la couche optique suivis d'autopsie. Revue neurol. I909, № 6.

Синдромъ зрительнаго бргра не представляеть большой рьдкости. Со времени опубликованія труда Roussy (1907г.), в' қоторомь собрано 13 наблюдевій, появились еще описанія Claude, Vincent'a и Klippel'я. Число же наблюденій, провњренныхъ встрытіемъ, крайне ограниqено (всего 4). Въ виду этого новые 2 случая съ данными аутопсіи представляють большой интересь. Въ одномъ изъ них' касалось бодьного 69 л., перенесшаго инсульть, посль⿱⺊口灬 чего наблюдался правосторонні гемипарезь съ рбзкими чувствительными разстройствами. Параличныя явленія быстро выровнялись и по истеченіп 6-ти недьль больной ходиль, симптома Babinski'аго не

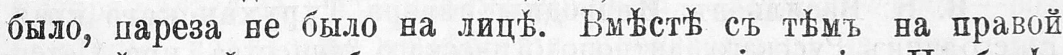
сторонь отмбчены были гемихорея и геміатаксія. Но болье всего выражевы были чувствительныя разстройства, котөрыя

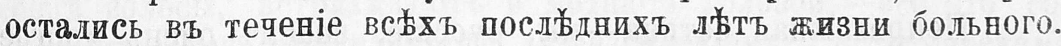
Таковы, во первыхь, сильныя боли въ лиц', требовавшія примьвенія большкхь дозь морфія; 2) рбзкое пониженіе кожвой чувствительности и 3) потеря мышечнаго и стереогностическаго чувства. Через 3 года-2 ой инсульть, вызвавшій полный параличъ дйвой сторовы сь потерей созванія и ва 
2 день смергь. При аутопсіи въ правомь полушаріи опредағлен'ь геморрагическій фокусъ, величиною въ большой орџхъ и разрушившій всю заднюю часть nucl. lenticularis на всемъ пространств采 от'ъ caps. ext. квутри до capsulam internam. Въ л"вомъ полушаріи найденъ старый, окруженный сумвой, геморрагическій фокусъ, продолговатой формы и занимающій заднюю и варужную часть зрштельнаго бугра. Данное наблюденіе особенно тишично и потому относится къ чистымъ формамъ синдрома врительнаго бугра.

2-ое наблюденіе нйсколько отличается. Въ немъ: 1) Гемиплегія имыла прогрессивный характеръ и развивалась в'ь н'Всколько приступовт, отдйленныхъ между собою большими промежутками времени. Съ самаго начала имьлись спастическія явленія. 2) Геміанәстезія была стойкой, но поверхностная чувсгвительность была поражена слабъе, чьмъ г.уубогая. 3) Боли на парализованной сторов' мен娄е интенсивными, чвмъ въ первомъ случан.

При аутопсіи найденъ очагъ приблизительно въ той же обдасти, кағъ и 1.ом' случањ, но болье давняго происхожденія, менъе правильнаго очертанія и съ большимъ распространеніемъ, а именно кром зрительнаго бугра повреждены были почти вся задняя $1 / 3$ caps. internae, часть 2-го и 3-го сегмента nucl. lenticularis, а тақже ретролентикулярвый сегментъ капсулы. Такимъ образомъ въ данномъ сдуча' бользневныд измьненія касались не только зрительнаго бугра, но и внутренней капсулы. Случаямъ этого рода должно быть присвоено названіе "Syndrome tholamique mixte" .

Н. Осокинг.

\section{Психологія народовъ.}

В. Н. Васильевъ. Инородцы сывера Туруханскаго края. Ежегодникъ Русскаго антропологическаго общества при Петербургскомъ университеть, 1908 r.

Непреложная истина-мы, русскіе, знаемъ очень многое и совсьиъ не зваемъ тольво нашей родины. Еще ведавно мы при изложеніи ученія о гретинизмъ ссылались на Пвейцарію, Италію и даже Кардильеры, тогда вакъ у насъ въ Сваветіи, Пріураль' и проч. гретиновъ больше, q'ым во 